\title{
Important Indicators Having Effect on Growth of SMEs in Albania
}

\author{
Dr. Bitila Shosha \\ Lecturer, "Aleksandër Moisiu" University, Business Faculty, Durrës, Albania \\ Email: bitilashosha@yahoo.com \\ Prof. Dr. Flutura Kalemi \\ Head of Finance and Accounting Department, Agricultural University of Tirana, \\ Faculty of Economy and Agro-Business, Tirana, Albania \\ Email: flutrakalemi@yahoo.com
}

\section{Doi:10.5901/ajis.2016.v5n3s1p575}

\section{Abstract}

One of the main challenges Albanian market is currently facing is the successful survival of Albanian small and medium entrepreneurs against the pressure of global market manufacturers/ suppliers, who can supply Albanian market with quality and competitive prices. Being under this pressure, it is, of course, particularly difficult for new manufacturers, established undertakings/ companies, newly established or old, to survive from the potential risk of failure during the first 3-4 years of their existence.This paper discusses some important issues and problems of financial situation, in general, and of the growth of small and medium enterprises in Albania. In addition, it presents, both theoretically and empirically, the relationship between the key performance indicators of SMEs growth. Some factors like number of years (age); number of employees; annual turnover, are subject to this analysis in order to see how SMEs are performing in Albania. For the analysis of qualitative and quantitative data, the linear regression and logistic regression models are used.

Keywords: SME growth; Number of years (age); Number of employees; Turnover; financial performance of SMEs.

\section{Literature Review for Indicators Having Effect on the Growth of SMEs}

Different theories have tried to identify the main factors determining the growth of a business. Such theories are divided into two main schools:

1. The first one, deals with the impact that size and age of business has on growth, while

2. The second deals with the impact of variables such as strategy, organization and characteristics of the business owners/managers.

Indeed, a huge number of researches have been focused on the relation between growth and business size and age.1 Thus, Evans (1987) analysed the effects of business size and age have on growth using data on US manufacturing businesses. Meanwhile, in a previous study, Gibrat has supposed the hypothesis that growth is independent on size, Evans (1987) concluded that business growth decreases depending on the size and age of business.

The empirical literature suggests that business growth is determined not only by traditional features, such as size and age, but also by other specific features of the business itself. Heshmati (2001), using data from the Swedish micro and small businesses, found out that the level of debt affects positively on the growth of sales. While Becchetti and Trovato (2002), while trying to analyse the Italian manufacturing industry, concluded that, besides traditional determinants such as age and size, business growth is determined by external finance, too.

The research of Reuber and Fischer (1997) reached in some conclusions about the choice of explanatory variables. Firstly, to understand better the determinants of SMEs growth in economies in transition, it is essential to

${ }^{1}$ Business growth requires capital. Regardless of size or age, access to capital is a matter of great importance. According to Timmons (1994), small businesses tend to obtain new capital from domestic sources, personal resources and informal investments. With the growth, businesses need capital injection and they lean on external sources, such as banks, public debt and equity markets. Myers and Majluf (1984) reach in the same conclusion. They argue that SMEs have a preference for capital sources according to a "rank", where gained profit is ranked first, then debt to banks, private foreign equity and at last, public debt or equity. 
specify an empirical model enabling the combination of traditional business characteristics (such as size and age) with more specific determining factors (such as total asset, leverage, internally generated funds, future development opportunities, and productivity factor). All these variables are closely related with the theoretical models explaining the growth of SMEs. Secondly, the Central and Eastern European countries are not homogenous, in terms of level of development and growth of SMEs, which vary from country to country. For this reason, the question we pose is about the common factors that can explain the growth and performance of SMEs.

\section{Empirical Analysis of SMEs Growth Explanatory Factors}

In line with previous studies, we argue that the growth of SMEs in the manufacturing, trade and service sector is strongly connected with the traditional business features Number of years (age); Number of employees; Turnover; etc.

For the first group we have used the linear regression where the dependent variable is profitability, and as explanatory factors, the numerical data variables are: Number of years (age); Number of employees; Turnover; Expenses for staff training; Costs of promotion.

Table 1: 1. Coefficients of variables

\begin{tabular}{|c|c|c|c|c|c|c|c|}
\hline \multirow{2}{*}{ Model } & \multicolumn{2}{|c|}{ Unstandardized Coefficients } & \multirow{2}{*}{$\frac{\text { Standardized Coefficients }}{\text { Beta }}$} & \multirow{2}{*}{$\mathrm{t}$} & \multirow{2}{*}{ Sig. } & \multicolumn{2}{|c|}{$90.0 \%$ Confidence Interval for B } \\
\hline & B & Std. Error & & & & Lower Bound & Upper Bound \\
\hline (Constant) & 5.807 & .363 & & 16.015 & .000 & 5.207 & 6.406 \\
\hline NoYEARS & -.067 & .029 & -.182 & -2.307 & .022 & -.116 & -.019 \\
\hline NoEMPLO & .070 & .045 & 123 & 1.555 & .122 & -.004 & 144 \\
\hline Turnover & .000 & .000 & 263 & 3.140 & .002 & .000 & .000 \\
\hline TRAIN & .002 & .001 & .125 & 1.225 & .222 &.- .001 & .004 \\
\hline PROMOTION & .001 & .002 & .051 & .547 & .585 &.- .002 & .004 \\
\hline
\end{tabular}

Source: Author's calculations

To determine the statistical significance of variables, we are using the significance limit (p-value $<0.05$ level). From the outputs of the programme using the enter method, we can determine as significant variables those variables having a significant value ( $p$-value $<0.05)$ according to the table 1.1:

- Number of years (AGE) $(P$-value $=0.022)$

- Annual turnover (turnover) $(P$-value $=0.002)$

Table 1: 2 Coefficients of the variables in equation

\begin{tabular}{|c|c|c|c|c|c|c|c|}
\hline \multirow{2}{*}{ Model } & \multicolumn{2}{|c|}{ Unstandardized Coefficients } & \multirow{2}{*}{$\begin{array}{c}\text { Standardized Coefficients } \\
\text { Beta }\end{array}$} & \multirow{2}{*}{$\mathrm{t}$} & \multirow{2}{*}{ Sig. } & \multicolumn{2}{|c|}{$90.0 \%$ Confidence Interval for B } \\
\hline & B & Std. Error & & & & Lower Bound & Upper Bound \\
\hline (Constant) & 5.539 & .350 & & 15.812 & .000 & 4.959 & 6.118 \\
\hline $\begin{array}{l}1 \text { Turnover } \\
\text { (Constant) }\end{array}$ & $\begin{array}{l}.000 \\
5.932\end{array}$ & $\begin{array}{l}.000 \\
.362\end{array}$ & .339 & \begin{tabular}{|l}
4.638 \\
16.410
\end{tabular} & .000 & $\begin{array}{l}.000 \\
5.334\end{array}$ & $\begin{array}{l}.000 \\
6.530\end{array}$ \\
\hline 2 NoYEARS & -.086 & .027 & -233 & -3.250 & .001 & -130 & .042 \\
\hline Turnover & .000 & .000 & .371 & 5.174 & .000 & .000 & .000 \\
\hline
\end{tabular}

Source: Author's calculations

By using the StepWise method, we manage to include in the model the statistically significant variables, according to the results of table 1.2 we obtain the following equation:

PERC.PROFITAB $=5.932-.086$ NoYEARS +.000 TURNOVER $+\varepsilon$

This model is statistically significant because of the significance value is within the limits of significance, table 1.2 (P-value $<0.05)$, thus we can say as significant factors: 
- Number of years (AGE) ( $p$-value $=0.003<0: 05)$

- Annual turnover (turnover) $(P$-value $=0.000<0.05$ level)

To test the relation PROFITAB (profitability), as dependent variable and the number of years, annual business turnover as independent variables, we assume the following hypothesis:

\title{
3. Hypothesis 1
}

\author{
$\mathrm{H}_{0}$ : Profitability is not affected by the number of years and business turnover. \\ $\beta_{1} \beta={ }_{2}=0$
}

\section{$\mathrm{H}_{1}$ : Profitability is affected by the number of years and annual turnover.}

$\beta_{1}$ or $\beta_{2} \neq 0$

Based on the results of the statistical processing using the linear regression model in SPSS version 21, from the table $\mathbf{1 . 2}$ we see that $\beta_{1}=-0.086 \neq 0$, just a coefficient different from zero is sufficient and hypothesis $\mathrm{H}_{0}$ is rejected, accepting the alternative hypothesis $\mathrm{H}_{1}$.

The statistical processing of linear regression confirms that there is a negative correlation between profitability and the number of years (Age). This indicates that the number of years in business for SMEs, according to their endogenous perceptions have a slightly negative impact on the business profitability.

However, despite such relationship is not expected to happen anytime, regarding the negative impact of the number of years in business to profitability, it may be argued that such negative impact may be caused by the pessimistic business climate existing nowadays in the market. It is known that recently, businesses are facing many difficulties in terms of liquidity, high cost of financing loans, tax increase, slow growth of gross domestic product, etc. All have an impact on the pessimistic perception entrepreneurs perceive themselves.

In the equation, we see that turnover, although a factor with significance value ( $p$-value $<0.05$ ), is presented by the data with an insignificant coefficient of 0.000 . It seems like the variable "turnover" does not affect the profitability of businesses. This indicates a financial conflict, it is beyond doubt as we expect turnover to affect business profitability. For this reason, with the SPSS version 21 we check again this correlation according to Pearson, between profitability and annual turnover. It results that turnover is a variable with a strong correlation determining the level of profitability.

To reach in a statistically and financially significant conclusion regarding the impact of annual turnover factor in the profitability of businesses, we change the value of profitability by Likert scale in dummy2. The processing of data by means of StepWise method shows the information given in table 1.3.

Table 1: 3. Coefficients of the variables in equation

\begin{tabular}{|c|c|c|c|c|c|}
\hline \multirow{2}{*}{ Model } & \multicolumn{2}{|c|}{ Unstandardized Coefficients } & Standardized Coefficients & \multirow{2}{*}{$t$} & \multirow{2}{*}{ Sig. } \\
\hline & B & Std. Error & Beta & & \\
\hline (Constant) & .727 & .063 & & 11.536 & .000 \\
\hline Turnover & 3.569E-005 & .000 & .234 & 3.094 & .002 \\
\hline
\end{tabular}

Source: Author's calculations

Using the StepWise method, we can include in the model statistically significant variables, according to results of table 1.3 we obtain the following equation:

PERC.PROFITAB $=0.727+3.569 \mathrm{E}-005$ TURNOVER $+\varepsilon$

The control of hypotheses about the impact of annual turnover to profitability using the coefficient as indicator: 


\title{
4. Hypothesis 2
}

\author{
$\mathrm{H}_{0}$ : Profitability is not affected by the business turnover. \\ $\beta_{1}=0$ \\ $\mathrm{H}_{1}$ : Profitability is affected by business turnover. \\ $\beta_{1} \neq 0$
}

In table 1.3 we see $\beta$ turnover $=3,569 \mathrm{E}-005$, with a significance value ( $p$-value $=0.002$ ), thus the alternative hypothesis $\mathrm{H}_{1}$ is accepted. The empirical evidences of other studies indicate that one of the most common metrics of business growth, relatively objective and measurable, is the increase of turnover. Annual turnover is relatively (methodologically) uncontroversial and the data tend to be easily available. ${ }^{3}$

\section{References}

Becchetti, L. and Trovato, G., 2002. "The determinants of growth for small and medium sized firms: the role of the availability of external finance". Small Business Economics, 19 (4), 291-306.

Bevan, J., Clark, G., Banerji, N. and Hakim, C. (1987)."Barriers to business start-up: a study of the flow in and out of self-employment", Department of Employment Research Paper No. 71.

Evans, D. S., 1987. "The relationship between firm growth, size and age: estimates for 100 manufacturing industries". The Journal of Industrial Economics, 35 (4), 567-581.

Evans, D.S. and Leighton, L.S. (1990). "Small business formation by unemployed and employed workers", Small Business Economics, 2 (4): pp. 319-330.

Freel, M. S. and Robson, P. J. A., 2004."Small firm innovation, growth and performance". International Small Business Journal, 22 (6), 561-575.

Heshmati, A. 2001. "On the growth of micro and small firms: evidence from Sweden". Small Business Economics, 17 (3), 213-228.

Myers, S. C. and Majluf, N. S., 1984. "Corporate financing and investment decisions when firms have information that investors do not have". Journal of Financial Economics, 13 (2), 187-221.

Reuber, R. and Fischer, E., 1997. "The influence of the management team's international experience on the internationalization behaviors of SMEs". Journal of International Business Study, 28 (4), 807-825.

Timmons, J. A., 1994. "New venture creation: entrepreneurship for the 21st century". McGraw-Hill/Burr Ridge, III: Irwin. 